\title{
Effects of Chloroquine and Hydroxychloroquine on the Cardiovascular System - Limitations for Use in the Treatment of COVID-19
}

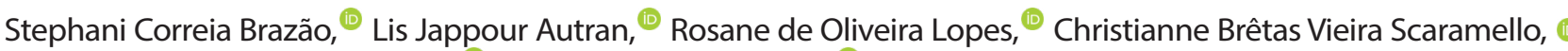 \\ Fernanda Carla Ferreira de Brito, ${ }^{[0}$ Nadia Alice Vieira Motta
}

Universidade Federal Fluminense (UFF), Instituto Biomédico, Niterói, RJ - Brazil.

\section{Abstract}

Chloroquine (CQ) and Hydroxychloroquine (HCQ) are antimalarial drugs, with anti-inflammatory properties that justify their use in the treatment of systemic lupus erythematosus and rheumatic diseases. A pandemic caused by the new coronavirus led the entire world's scientific community to look for drugs already available on the market, capable of exercising beneficial actions in the fight against the disease. Preliminary studies in patients, as well as in vitro studies, suggested possible therapeutic effects associated with the use of HCQ and CQ in the treatment of COVID-19. Despite controversies over the effects of these drugs in combating the "cytokine storm" associated with COVID and the dismal of results in different clinical trials in Brazil, their use has been encouraged and several ongoing investigative studies are underway. In addition to the possible beneficial effects on the prognosis of patients with SARS-CoV-2, such drugs include varied effects on the cardiovascular system, ranging from positive developments related to their vasodilator properties to potential negative effects, such as cardiotoxicity. This work presents the main effects exerted by these drugs on the cardiovascular system, in order to contribute to a scientific discussion about the repurposing of these drugs in the context of COVID-19.

\section{Introduction}

COVID-19, a disease caused by the coronavirus (SARS-CoV-2), was discovered in Wuhan, China,

\section{Keywords}

Cardiovascular System; Chloroquine/toxicity; Hydroxychloroquine/toxicity; Betacoronavirus; COVID-19; Azithromycin/ therapeutic use. and spread rapidly throughout the world (World Health Organization - WHO). ${ }^{1}$ Recent reports have highlighted the possible benefits of chloroquine (CQ) and hydroxychloroquine (HCQ) use in COVID-19 treatment. ${ }^{2}$ Chloroquine emerged in the 1940s and is clinically used in malaria treatment due to its effectiveness, low cost, safety, and easy manufacture. CQ was synthesized for the first time in 1934, and although its antimalarial properties have been identified, its development was blocked due to the high toxicity observed for this class of drugs. Subsequently, CQ was resynthesized, presenting less toxicity and reported to be superior to sontoquine and quinacrine in malaria treatment. ${ }^{3} \mathrm{HCQ}$, clinically introduced in 1955, is an analogue of CQ, also used on malaria treatment, sharing the same mechanism of action. Its clinical indications include skin diseases, sarcoidosis, extra-intestinal amebiasis, chronic $Q$ fever, rheumatoid, and autoimmune diseases. ${ }^{4,5}$

Its antimalarial actions are associated with lysosomal activity and autophagy signaling pathways. ${ }^{6} \mathrm{CQ}$ and $\mathrm{HQ}$ bind preferentially to phospholipids, accumulating in lysosomes which promote changes in $\mathrm{pH}$ and direct inhibition of lysosomal enzymes. These effects lead to the impairment of intracellular degradation processes, along with the accumulation of pathological metabolic products (especially phospholipids and glycogen). Histologically, these seem to be vacuolar granule cell mutations and ultrastructural as lamellar membrane inclusion bodies and as "curvilinear bodies" in the cytoplasm. ${ }^{7}$

HCQ has some benefits, such as a reduced incidence of kidney injury and a lower risk of developing serious comorbidities, including venous thromboembolism and pregnancy complications. ${ }^{8-10}$ It is considered an essential drug for the treatment of systemic lupus erythematosus (SLE), reducing the impact of the disease and improving 
patient survival. On the other hand, it has a potential retinotoxic effect, a factor which can limit the dose to be used. ${ }^{11}$ A previous report indicated that HCQ has less toxic potential than CQ due to the hydroxyl group, which limits the HCQ's ability to cross the blood-retinal barrier. ${ }^{12}$

Investment in the development of malaria treatments has led to a decrease in cases, reducing morbidity and mortality of the disease. WHO estimates that between 2000 and 2010, the incidence of malaria was reduced, and this is due to vector control, improvements in the health system, effective treatments, an increase in notifications, and cases of surveillance. ${ }^{13}$ In addition to their antimalarial effects, CQ and HCQ have immunomodulatory actions that are recommended for the treatment of autoimmune diseases. Moreover, it has recently been shown to be effective in reducing cardiovascular risk factors, including hyperlipidemia and hyperglycemia. ${ }^{14,15}$

The adverse effects triggered by the long-term administration of CQ and HCQ were first described in 1948. ${ }^{16-18}$ The first publications reported specific toxic effects, such as retinopathy, ${ }^{19}$ neuromyopathy, ${ }^{20,21}$ cardiomyopathy, ${ }^{22}$ and third-degree atrioventricular block. ${ }^{23}$ The main reported cardiovascular effects are: vasodilation, hypotension, hypokinesia, and cardiac arrhythmias. ${ }^{24}$ The toxic effect is usually dose-dependent. HCQ is melanotropic, and it bioaccumulates in tissues with a high melanin content, such as skin, ciliary bodies, and retinal pigment epithelium. ${ }^{25}$ Therefore, allergic patients, psoriasis, porphyria, and alcoholism are more susceptible to cutaneous side effects. HCQ has a toxic potential in pediatric patients, ${ }^{26}$ but one study indicated no potential cardiotoxic fetuses after HCQ use during pregnancy. ${ }^{27}$

CQ and HCQ are administered orally, with bioavailability between $70-80 \%$, a long half-life time (30-60 days) and a large volume of distribution (116$285 \mathrm{~L} / \mathrm{kg}){ }^{28}$ Like all aminoquinolines, metabolites are eliminated through the kidney and liver, thus their excretion decreases in patients with renal or hepatic dysfunction, placing them at high risk for developing toxic effects. ${ }^{25}$ Even after treatment is discontinued, they remain detectable in the urine for years. ${ }^{29}$

In general, CQ and HCQ can be considered safe drugs, and side effects are usually mild and transient. However, the therapeutic index is narrow and CQ intoxication has been associated with cardiovascular disorders which can be fatal. ${ }^{30}$ Therefore, the use of CQ and HCQ should be restricted and self-medication poses potential risk to patients.
In vitro antiviral activity of CQ has been described since the late $1960 \mathrm{~s}^{31-33}$ and its role on inhibition of SARS-CoV-1 replication has been shown in Vero E6 cell cultures. ${ }^{34}$ In animal models, CQ has presented important effects in a variety of viruses, including human coronavirus OC43, ${ }^{34}$ enterovirus EV-A71, ${ }^{35}$ Zika virus, ${ }^{36}$ and influenza A $\mathrm{H} 5 \mathrm{~N} 1 .{ }^{37}$ However, CQ was unable to prevent influenza infection in a randomized, double-blind, placebocontrolled clinical trial, ${ }^{38}$ as well as having no effects in dengue-infected patients in a randomized clinical trial in Vietnam. ${ }^{39} \mathrm{CQ}$ was also active in ex vivo, but not in in vivo studies against ebolavirus, ${ }^{40,41}$ Nipah virus, ${ }^{42}$ and influenza virus in different animal models. ${ }^{43}$ Regarding chikungunya virus (CHIKV), CQ showed promising in vitro antiviral activity ${ }^{44,45}$ but increased replication of the alphavirus in several animal models. ${ }^{46,47}$ These effects are most likely associated with its immunomodulatory and anti-inflammatory properties in vivo. ${ }^{48-50} \mathrm{In}$ a non-human primate model of CHIKV infection, CQ treatment has shown to aggravate acute fever and delay the cellular immune response, leading to incomplete viral clearance. ${ }^{47}$ To date, it is important to emphasize that CQ has not been effective in any human acute viral infection. $39,45,47,51,52$

\section{Effects of CQ and HCQ on the Cardiovascular System}

The effects of CQ and HCQ on the cardiovascular system are diverse. In the literature, positive effects are reported in patients who used HCQ for SLE treatment, such as a reduction in the incidence of acute myocardial infarction, coronary artery disease, and peripheral arterial disease. These effects are associated with a potential antiplatelet, antithrombotic, and antihypertensive activity of HCQ. ${ }^{53}$ In addition, reports indicate that HCQ has a potential to reduce the diabetes development, lowdensity lipoprotein (LDL) levels, as well as atherosclerosis progression which can contribute to the decrease in cardiovascular events. ${ }^{54}$

However, despite its anti-inflammatory effects and potential antithrombotic action, the literature indicates cardiotoxicity cases with the use of CQ and HCQ. At the molecular level, CQ and HCQ are amphipathic cationic drugs with the capacity to bind to myocyte phospholipids and accumulate in lysosomes, thereby inhibiting their enzymatic activity. This process impairs intracellular degradation, allowing the accumulation of toxic metabolic products. ${ }^{55} \mathrm{~A}$ study conducted by Chatre et al. ${ }^{56}$ demonstrated that cardiac disorders associated with HCQ and CQ treatment lead to ventricular 
arrhythmias and irreversible damage, which can lead to death. Cardiac side effects are less reported than effects such as retinopathy, but in some cases, they can be severe and irreversible.

Among the main reported effects, conduction disorders and cardiomyopathy, usually with hypertrophy and congestive heart failure, are highlighted. As the clinical characteristics of cardiotoxicity are nonspecific, the identification and monitoring of potentially affected patients is extremely important. Diagnostic confirmation requires histological examination of myocardium associated with electron microscopy. Reports in the literature indicate cases of hypertrophic cardiomyopathy, ${ }^{57-64}$ restrictive cardiomyopathy, ${ }^{65}$ biventricular dilation, ${ }^{66-67}$ and left chamber dilation. ${ }^{66}$ The development of cardiomyopathy is recurrent in patients who used CQ and HCQ, and in some cases it is reversed after treatment discontinuation. ${ }^{60-63,67-69}$

Some previous risk factors can increase the incidence of cardiomyopathy, The most important of which are: age, sex, time of use, high doses, pre-existence of heart disease, and renal failure. ${ }^{69}$ The HCQ use is associated with diffuse ventricular myocardial thickening, the main secondary myocardial alteration being related to its use. ${ }^{18,70}$ In addition, patients with severe heart failure, a worsening of exercise capacity, dyspnea, and angina can also be observed..$^{68}$

In the literature, it is described that the CQ and HCQ use can present long-term effects, even after the diagnosis and immediate suspension of treatment, with clinical and histological characteristics for years. ${ }^{18,61}$ Thus, cardiomyopathy is a relevant adverse effect associated with CQ and HCQ treatment. Early diagnosis and periodic cardiological follow-up of the patients are essential for preventing cardiotoxicity and, consequently, the evolution of heart failure.

In addition to morphofunctional changes in cardiomyocytes, conduction disorders have also been reported. Conduction disorders are reported more frequently after chronic treatment with HCQ and CQ, as seen in patients on long-term treatment for SLE, in which cumulative doses are high. However, it is important to note that patients affected by severe form of COVID-19 often have other comorbidities and/or use pro-arrhythmic drugs such as azithromycin, factors that increase the risk of conduction disorders. ${ }^{71} \mathrm{HCQ}$ and $\mathrm{CQ}$ block $I_{\mathrm{Kr}}$ potassium channels in cardiomyocytes, which can result in conduction disorders such as: prolongation of the QT interval, atrioventricular blocks, enlargement of the QRS complex, depression of the ST segment, and inversion of the $\mathrm{T}$ wave, ${ }^{72,73}$ which can result in conduction disturbances, including QT prolongation, atrioventricular block, expansion of the complex QRS, depression of the ST segment, and T-wave inversion. ${ }^{74}$ Some reports of HCQ intoxication have been described in the literature, such as the occurrence of sudden ventricular tachycardia after the use of high doses of the drug. ${ }^{75}$ As well as quinidine, an antiarrhythmic drug with a chemically similar structure, ${ }^{76} \mathrm{CQ}$ and HCQ have the potential to cause changes in the QT interval, a risk factor for the development of ventricular tachyarrhythmia. ${ }^{77-80}$ Long QT syndrome is an electrophysiological disorder characterized by an increase in the QT interval and abnormalities in the T wave, whose clinical consequences can be dizziness, syncope, and sudden death. ${ }^{81}$

In the literature, cases of syncope and torsade de pointes secondary to HCQ-induced cardiotoxicity have been described. ${ }^{79,82}$ A study developed by van den Broek et al. ${ }^{83}$ demonstrated that CQ treatment was able to generate significant prolongation of the corrected QT interval (QTc) in 23\% of the patients with COVID-19 ( $\mathrm{n}=95)$. In a cohort study conducted with 201 patients undergoing treatment for COVID-19 with HCQ (95\%) and CQ (5\%), with or without azithromycin, a high incidence of QTc interval prolongation was observed when compared to the baseline; $8.9 \%$ of the patients had a QTc interval above $500 \mathrm{~ms}$, of whom $3.5 \%$ were indicated for suspension of therapy and $1 \%$ were submitted to lidocaine use in order to reverse the condition. ${ }^{84} \mathrm{~A}$ case of torsade de pointes was also reported by Szekely et al. ${ }^{85}$ in a patient hospitalized with COVID-19, whose QTc interval was excessively prolonged (627 ms; baseline of $462 \mathrm{~ms}$ ) after the introduction of HCQ therapy. In COVID-19 patients treated with the HCQ and azithromycin association, torsade de pointes has been reported. ${ }^{86,87}$ To avoid electrophysiological complications, cardiological followup during treatment with HCQ or CQ is recommended, with emphasis on electrocardiographic monitoring of the QTc interval.

The occurrence of syncope associated with CQ use may also originate in cases of atrioventricular block or bundle branch block. ${ }^{88}$ A retrospective study conducted with 103 patients undergoing treatment for SLE has shown that 18 cases of conduction disorder were identified; 5 cases presented third degree atrioventricular block, of which 4 were using CQ in the treatment protocol. ${ }^{89}$ In addition, cases of right and left bundle branch secondary 
to CQ use have also been reported $(90,91)$. The treatment of third-degree atrioventricular block usually requires a pacemaker implant to reverse the condition. ${ }^{75,88}$ McGhie et al. ${ }^{75}$ observed 453 patients treated with HCQ and CQ drugs, and found, through electrocardiographic exams, that conduction disorders are more prevalent than structural changes, with right branch block being the most common among electrophysiological disorders, followed by bradycardia and first-degree atrioventricular block.

Pulmonary hypertension (PH) is a hemodynamic condition caused by an increase in mean pulmonary arterial pressure, caused by pulmonary dysfunctions or cardiovascular changes. ${ }^{92}$ In a model of $\mathrm{PH}$ induced in rats, CQ exerted a pulmonary vasodilator effect. The authors suggest that this effect may be related to direct or indirect blockage of voltage-operated calcium channels, store-operated calcium channels, and receptor-operated calcium channels on pulmonary artery smooth muscle cells. The potential therapeutic of CQ in $\mathrm{PH}$ is probably associated with the combination of its vasodilator, antiproliferative, and autophagy inhibitory effects. ${ }^{93}$

CQ and HCQ were able to prevent right ventricular hypertrophy and vascular remodeling, as well as improve contractility and cardiac output parameters in PH experimental model. In this model, it was observed that CQ and HCQ treatment inhibited monocrotalineinduced autophagy, preventing the p62 expression, a key protein in autophagy modulation. ${ }^{94}$ In addition, CQ has a therapeutic potential in the management of hereditary pulmonary hypertension, since it has the capacity to increase the expression of type II bone morphogenetic protein receptor (BMPR -II) on the cell surface. ${ }^{95}$ On the other hand, despite the vasodilatory effects, the cardiotoxicity caused by CQ and HCQ may predispose PH development due to pulmonary circulation overload, as a result of congestion triggered by flow disorders through the left atrium and ventricle. ${ }^{96}$

In a systematic review by Chatre et al., ${ }^{56} 86$ studies involving patients undergoing CQ or HCQ treatment were evaluated, in which $3.9 \%$ developed $\mathrm{PH}$. In addition to this pathology, other important changes were observed, such as: conduction disorder (85\%), ventricular hypertrophy (22\%), hypokinesia (9.4\%), and heart failure (26.8\%). Therefore, it was possible to observe that $\mathrm{PH}$, even if present, did not present such a significant prevalence in patients who used the drug. Table 1 shows a compilation of studies that describe electrophysiological and morphofunctional cardiovascular changes in patients after chronic treatment with CQ and HCQ.
Drug Interactions of Clinical Importance Associated with CQ and HCQ Use

Patients with rheumatoid arthritis and SLE are treated chronically with CQ or HCQ. The continuous treatment exposes patients to the development of significant side effects, as well as contributes to an incidence of adverse reactions caused by drug interactions. CQ and HCQ interact with several drugs of clinical relevance, mainly through microsomal enzymes belonging to the cytochrome P450 family (CYP), culminating in the impairment of hepatorenal clearance caused by these therapies. ${ }^{97}$ Drug interactions are of great clinical importance, and for this reason, they should receive particular attention. CQ and HCQ are substrates of CYP2D6, CYP3A4, CYP2C8, and CYP1A1, and may change the plasma levels of many drugs and vice versa. ${ }^{98}$

CQ and HCQ interact with clinically important drugs, such as antibiotics, aspirin, paracetamol, cholestyramine, proton pump inhibitors, H2 receptor antagonists, imipramine, methotrexate, cyclosporine, caffeine, metoprolol, among others. Analgesics, often used as acetylsalicylic acid and paracetamol, need more attention. CQ both increases the maximum plasma concentrations of paracetamol ${ }^{99}$ and affects its clearance. ${ }^{100}$ In vitro, HCQ inhibits the activity of plasmatic esterases responsible for aspirin degradation, thereby contributing to increase their circulating levels. ${ }^{101}$

The use of CQ and HCQ associated with drugs used in the treatment of cardiovascular diseases requires adequate monitoring in order to minimize the possible cardiotoxic effects inherent to the combination therapy. CQ can increase the plasma digoxin concentration up to 4-fold and precipitates clinical manifestations, such as arrhythmia and cardiotoxicity. ${ }^{102}$ Additionally, metoprolol can present changes on its plasmatic concentration when used concomitantly with HCQ. This interaction occurs through competition for the same metabolizing enzyme of both drugs, CYP2D6, resulting in an increase of concentration and bioavailability of metoprolol. ${ }^{103}$

Due to the pandemic caused by COVID-19, several clinical studies have been conducted in order to characterize a safe and effective therapy for the treatment of this disease. Some already published studies emphasize that HCQ associated with azithromycin presents potentialized effects, exerting promising actions in the COVID-19 treatment. ${ }^{104,105}$ In addition, a study by Fantini J et al. ${ }^{106}$, using a dynamic molecular simulation technique, demonstrated a synergistic antiviral effect 


\begin{tabular}{|c|c|c|c|c|}
\hline Reference & $\begin{array}{l}\text { Therapeutic } \\
\text { Indication }\end{array}$ & $\begin{array}{l}\text { Electrophysiological } \\
\text { alteration }\end{array}$ & Morphofunctional alteration & Intervention \\
\hline Nord et al., 2004 & SLE & Atrial flutter & $\begin{array}{l}\text { LV and RV dilation; LVPW } \\
\text { hypokinesia; (EF: 20\%) }\end{array}$ & $\begin{array}{l}\text { HCQ suspension; radiofrequency } \\
\text { ablation; cardioverter implantation. }\end{array}$ \\
\hline Nord et al., 2004 & SLE & VPC & $\begin{array}{c}\text { LA e LV dilation; } \\
\text { global hypokinesia; SAH and } \mathrm{PH} \\
\text { (EF: 23\%) }\end{array}$ & HCQ suspension \\
\hline Lenfant et al., 2020 & SCLE & $\mathrm{CD}$ & $\begin{array}{l}\text { cardiomyopathy } \\
\text { (LV hypertrophy) }\end{array}$ & CQ suspension \\
\hline Cervera et al., 2001 & SLE & Complete heart block & $\begin{array}{l}\text { Restrictive cardiomyopathy } \\
\text { (EF: } 36 \%)\end{array}$ & $\begin{array}{l}\text { Pacemaker implantation; } \\
\text { CQ suspension }\end{array}$ \\
\hline Gentille et al., 2011 & SLE & Complete heart block & - & $\begin{array}{c}\text { Pacemaker implantation; CQ } \\
\text { suspension }\end{array}$ \\
\hline Lee et al., 2010 & RA & $\begin{array}{l}\text { Sinus arrest; } \\
\text { junctional rhythm }\end{array}$ & $\begin{array}{l}\text { Hypertrophic cardiomyopathy; } \\
\text { (EF: } 44 \%)\end{array}$ & $\begin{array}{l}\text { Pacemaker implantation; } \\
\text { HCQ suspension }\end{array}$ \\
\hline Chatre et al., 2016 & SLE & - & $\begin{array}{l}\text { Cardiomyopathy; } \\
\text { (LV hypertrophy) }\end{array}$ & HCQ suspension \\
\hline $\begin{array}{l}\text { Yogasundaral et al., } \\
2018\end{array}$ & PR & Bifascicular block & $\begin{array}{l}\text { Cardiomyopathy; } \\
\text { (EF: } 60-67 \%)\end{array}$ & CQ suspension \\
\hline Baguet et al., 1999 & SLE & $\begin{array}{c}\text { Heart block; PR interval } \\
\text { prolongation }\end{array}$ & $\begin{array}{c}\text { Cardiomyopathy; } \\
\text { (LV hypertrophy) (EF: 45\%) }\end{array}$ & $\begin{array}{l}\text { Pacemaker implantation; } \\
\text { CQ suspension }\end{array}$ \\
\hline Naqvi et al., 2005 & SLE & - & $\begin{array}{c}\text { Cardiomyopathy; } \\
\text { (LV and RV hypertrophy) (EF: 60\%) }\end{array}$ & $\begin{array}{l}\text { Pacemaker implantation; } \\
\text { CQ suspension }\end{array}$ \\
\hline Dogar et al., 2017 & RA & - & (EF: $55 \%)$ & HCQ suspension \\
\hline Cotroneo et al., 2007 & SLE, RA & Incomplete RBBB & $\begin{array}{c}\text { Cardiomyopathy; } \\
\text { (LV hypertrophy) (EF: 40\%) }\end{array}$ & HCQ suspension \\
\hline Reffelmann et al., 2015 & RA & $\begin{array}{l}\text { Complete RBBB; } \\
\text { sinus arrest; } \\
\text { junctional rhythm }\end{array}$ & $\begin{array}{l}\text { Cardiomyopathy; } \\
\text { (LV hypertrophy); } \mathrm{PH}\end{array}$ & $\begin{array}{c}\text { CQ suspension; } \\
\text { Pacemaker implantation }\end{array}$ \\
\hline Abid et al., 2020 & SLE & Complete heart block & - & $\begin{array}{c}\text { Pacemaker implantation; } \\
\text { HCQ suspension }\end{array}$ \\
\hline
\end{tabular}

Cubero et al., 1993

SLE Complete heart block
(LV and RV hypertrophy)

(EF: $42 \%$ )

\begin{tabular}{|c|c|c|c|c|}
\hline Reuss-Borst et al., 1999 & RA & Complete heart block & - & Pacemaker implantation \\
\hline Reuss-Borst et al., 1999 & SLE & Complete heart block & - & Pacemaker implantation \\
\hline Saussine et al., 2009 & SLE & Complete heart block & - & $\begin{array}{c}\text { Pacemaker implantation; CQ } \\
\text { suspension }\end{array}$ \\
\hline Saussine et al., 2009 & SLE & $\begin{array}{c}\text { LAHB; LPHB; Complete } \\
\text { heart block }\end{array}$ & hypokinesia & Pacemaker implantation \\
\hline $\begin{array}{l}\text { Costedoat-Chalumeau } \\
\text { et al., } 2007\end{array}$ & SLE & Complete heart block & $\begin{array}{l}\text { LV and RV enlargement; } \\
\text { (EF: } 24 \%) ;\end{array}$ & $\begin{array}{l}\text { Heart transplantation; } \\
\text { CQ suspension }\end{array}$ \\
\hline Aslanger et al., 2008 & HPul & Complete heart block & - & Pacemaker implantation \\
\hline Chen et al., 2006 & SLE & $\begin{array}{c}\mathrm{TdP} ; \mathrm{PR} \text { interval } \\
\text { prolongation with VPC }\end{array}$ & - & HCQ suspension \\
\hline \multicolumn{5}{|c|}{$\begin{array}{l}\text { Abbreviations - CD: conduction disorder; EF: ejection fraction; HPul: pulmonary hemosiderosis; LA: left atrium; LAHB: left anterior hemiblock; LPHB: } \\
\text { left posterior hemiblock; LV: left ventricle; LVPW: left ventricle posterior wall; PH: pulmonary hypertension; PR: palindromic rheumatism; RA: rheumatoid } \\
\text { arthritis; RBBB: right bundle branch block; RV: right ventricle; SAH: systemic arterial hypertension; SCLE: subacute cutaneous lupus erythematosus; SLE } \\
\text { systemic lupus erythematosus; TdP: torsades de pointes; VPC: ventricular premature contraction. }\end{array}$} \\
\hline
\end{tabular}


of HCQ combined with azithromycin in the COVID-19 treatment. However, both treatments are able to promote prolongation of QT interval, which trigger refractory ventricular arrhythmia, even when used alone..$^{79,107}$ Chorin et al ${ }^{86}$ reported cases of torsade de pointes in patients with COVID-19 who were treated with the HCQ and azithromycin association. In addition, they observed a prolongation of the QTc interval above $500 \mathrm{~ms}$ in $23 \%$ of the cases $(n=211)$. The French Pharmacovigilance Database reported that $14 \%$ of the adverse effects linked to the association of HCQ with azithromycin corresponded to blockage in the cardiac conduction system $(n=120){ }^{87}$ Although CQ and HCQ show in vitro antiviral activity against COVID-19 in some studies, there is no robust evidence to demonstrate the clinical benefit of combined HCQ and azithromycin therapy in reducing the mortality of hospitalized patients with a severe form of COVID-19. Moreover, the deleterious effects on the cardiovascular system are notorious and should not be neglected. .5,108 $^{-10}$

Other important drug interactions are associated with the widespread use of CQ and HCQ with immunosuppressive drugs in the treatment of rheumatoid arthritis and SLE, such as methotrexate and cyclosporine. CQ and HCQ impair the methotrexate absorption by $\mathrm{pH}$ variation, thereby reducing its oral bioavailability, which contributes to sub-therapeutic effects of methotrexate. ${ }^{109,110}$ CQ and HCQ may also increase cyclosporine plasma levels, enhancing the risk of nephrotoxicity. Thus, cyclosporine use should be monitored during combination therapy in order to avoid potentially toxic effects. ${ }^{111,112} \mathrm{CQ}$ is also able to reduce the bioavailability of some classes of antibiotics, such as penicillin and quinolones, limiting their therapeutic effects. ${ }^{113,114}$

On the other hand, drugs that raise gastric $\mathrm{pH}$ can reduce the CQ and HCQ bioavailability, such as proton pump inhibitors and $\mathrm{H} 2$ receptor antagonists, restricting their therapeutic effects. ${ }^{115}$ Since a range of drug interactions involving the long-term use of CQ and HCQ and these drugs have a low therapeutic index, it is extremely important to monitor patients who continuously use these drugs to ensure both clinical efficacy and safety.

\section{Effects of Chloroquine and Hydroxychloroquine on other Systems}

Retinopathy is an adverse effect widely described as a consequence of CQ and HCQ use. However, the mechanism involved in toxicity associated with retinopathy is not fully understood. ${ }^{116}$ Retinal toxicity can cause irreversible visual loss. The result of the analysis of 2,361 patients using HCQ revealed an overall prevalence of $7.5 \%$ of toxicity in patients treated for more than 5 years and $20 \%$ in those treated for more than 20 years. ${ }^{117}$ The main identified risk factors were doses of HCQ above $5 \mathrm{mg} / \mathrm{kg}$ or CQ above $2.3 \mathrm{mg} / \mathrm{kg}$, duration of use for more than 5 years, previous renal failure, use of tamoxifen, and macular disease. ${ }^{116,118}$

Ponticelli and Moroni ${ }^{119}$ observed that $10 \%$ of patients treated with HCQ developed corneal deposits which were dose-dependent, transient and reversible. However, in most cases, the retinopathy was irreversible. It is important that patients treated with HCQ and CQ receive a warning of the risk of toxicity as well as a periodic evaluation. The most common visual symptoms include reading and sight difficulties, photophobia, and visual blur.

The multifocal electroretinography (mfERG) provides objective documentation of visual functions, and exerts an important role in screening and evaluation in order to manage the discontinuation of treatment. However, further studies are needed to define the relationship between the time of physiological evolution and structural abnormalities. In addition, the sensitivity and specificity of mfERG can be assessed when compared to automated visual fields, fundus autofluorescence imaging, and optical coherence tomography. ${ }^{120} \mathrm{~A}$ recent study showed that retinopathy progresses for 3 years even after HCQ treatment suspension. In this same study, they have observed more severe changes in patients who received doses above $11 \mathrm{mg} / \mathrm{kg} /$ day. Thus, it is extremely important to periodically evaluate patients who use these drugs in order to diagnose the early stages of development of retinopathy and provide a detailed analysis of risk and progression of visual loss in these patients..$^{25}$

Undesirable dermatological events include such pathologies as psoriasis, alopecia, itching, skin pigmentation and mucous membranes, photosensitivity, and skin rashes. ${ }^{121}$ Another adverse effect reported is myopathy, the main symptoms of which are muscle weakness, increased levels of muscle enzymes, electromyographic changes, and histological lesions. ${ }^{122}$

Chloroquine and Hydroxychloroquine in the COVID-19 Treatment: Impact on the Cardiovascular System

Diseases that affect the cardiovascular system represent a risk factor for patients with COVID-19, as well as diabetes, pulmonary disorders, and obesity. 
Therefore, such individuals are more susceptible to developing the severe form of the disease. ${ }^{123-125}$ On its surface, SARS-CoV-2 expresses proteins that interact with its receptor, ECA2. ${ }^{126}$ Tissues that widely express this receptor are more vulnerable to viral invasion, such as lungs, cardiovascular system, intestine, kidneys, central nervous system, and adipose tissue. ${ }^{127,128}$

Patients with COVID-19 have shown a higher incidence of acute heart failure, ${ }^{123,129}$ and critically ill patients are more susceptible to present cardiovascular damage. ${ }^{123,130,131}$ Mehta et al. ${ }^{132}$ have observed that patients with COVID-19 have a cytokine production profile similar to secondary hemophagocytic lymphohistiocytosis (sHLH), which is associated with poor prognosis. This phenomenon has been described as "cytokine storm", characterized by an unregulated response of type 1 and type 2 auxiliary T cells. ${ }^{123}$ This "cytokine storm" is marked by exacerbated increase in interleukins (IL), such as IL-1, IL-6, and IL-7, granulocyte colony stimulating factor (G-CSF), protein 10 induced by $\gamma$-interferon (CXCL10/IP-10), monocyte chemotactic protein 1 (MCP$1)$, inflammatory macrophage protein $1-\alpha(\mathrm{MIP}-1 \alpha)$, and tumor necrosis factor- $\alpha$ (TNF- $\alpha$ ). Mortality predictors from a recent retrospective, multicenter study of 150 confirmed cases of COVID-19 in Wuhan, China, included elevated ferritin (mean $1297.6 \mathrm{ng} / \mathrm{mL}$ in non-survivors vs. $614.0 \mathrm{ng} / \mathrm{mL}$ in survivors; $\mathrm{p}<0.001$ ) and IL-6 ( $\mathrm{p}$ $<0.0001$ ), suggesting that mortality may be associated with hyperinflammation promoted by the virus. ${ }^{131}$

Cardiac injury is related to direct damage caused by viral replication and cytokine storm. In addition, respiratory dysfunction and hypoxia generated by COVID-19 can also cause damage in cardiomyocytes. ${ }^{123,133,134}$ Clerkin et al. ${ }^{135}$ reported that $7 \%$ of infected patients developed myocardial injury, diagnosed through echocardiographic examination or electrocardiogram, and presented elevated troponin I levels. Considering that the cardiovascular system is directly affected by SARS-CoV-2 infection, therapy with drugs that have a cardiotoxic potential becomes even more contraindicated.

Although the in vitro antiviral effects of CQ have been demonstrated by reducing the viral replication of SARS$\mathrm{CoV},{ }^{34,136}$ inhibiting HIV replication, ${ }^{50}$ in addition to in vivo antiviral effects reported in an H1N1 animal model, ${ }^{37}$ clinical studies demonstrate controversial data regarding its effects on reducing viral loads in humans. Engchanil et al. ${ }^{51}$ reported that CQ was not effective in improving clinical, immunological, and virological parameters in HIV-infected pediatric patients, and tended to cause an increase in undesirable gastrointestinal events. In a double-blind randomized study with 307 hospitalized adults with dengue fever, it was observed that CQ was not able to reduce viremia, ${ }^{39}$ and actually increased the incidence of adverse gastrointestinal effects. A study performed by Borges et al. ${ }^{137}$ showed that CQ apparently reduced symptoms related to the disease, but was not able to decrease the time infection caused by dengue virus. CQ treatment in Chikungunya infection was evaluated in a double-blind, placebo-controlled study developed by Lamballerie et al., ${ }^{45}$ which indicated that CQ did not reduce viral loads and in fact increased the incidence of arthralgia when compared to the placebo arm. The work performed by Gautret et al., ${ }^{104}$ reported in March 2020, demonstrated that HCQ exerts beneficial effects in COVID-19 treatment. However, the study showed several limitations that were clarified by Toumi and Aballea, ${ }^{138}$ such as a reduced number of enrolled patients, outcome measures, and a lack of homogeneity in both the control and treated groups. These questions compromise comparability between arms and lead to a deficiency in the control of the occurrence of type I statistical error and other inconsistencies in the protocol study.

Due to the widespread use of HCQ in hospitalized patients with COVID-19 without robust evidence to support its use, several clinical trials have been performed to confirm or refute its efficacy and safety in these patients. A randomized, controlled, multicenter clinical study conducted in China, evaluated 150 hospitalized patients with moderate and severe COVID-19. HCQ treatment did not promote additional beneficial effects in eliminating viral loads when compared to standard treatments, in addition to causing significant adverse events. ${ }^{139}$ An observational study by Geleris et al., ${ }^{140}$ evaluated 1,446 patients with COVID-19 and found that HCQ treatment neither reduced nor increased the risk of intubation or death in the evaluated patients. Another observational study evaluated the HCQ effectiveness in 181 patients admitted with COVID-19 pneumonia who needed oxygenotherapy. In this study, the use of HCQ was not indicated for these patients, since treatment did not reduce the length of hospital stay nor the mortality rate. In addition, $10 \%$ of patients treated with HCQ have presented significant electrocardiographic changes and discontinued treatment. ${ }^{141}$ Finally, a recent clinical study conducted with 1,438 hospitalized patients diagnosed with COVID-19, has shown that HCQ therapy is not associated with a reduction in mortality by COVID-19. ${ }^{52}$ 
Given the unproven efficacy, it is possible to promote cardiotoxicity in isolated or combined therapy with other drugs commonly used in the treatment of COVID-19, in addition to the fact that patients infected with COVID-19 may have direct damage in their cardiovascular system. It is important to evaluate critically and ethically if the CQ and HCQ use is necessary as a therapeutic approach to SARS-CoV-2 infection, ${ }^{142}$ considering all the risks associated with their use (figure 1).

\section{Conclusion}

Chloroquine and hydroxychloroquine represent drugs with a potential benefit in the treatment of several pathologies, presenting important anti-inflammatory and immunomodulatory actions, with their pharmacological effects evidenced in the chronic treatment of autoimmune diseases. However, their side effects should not be overlooked, especially ophthalmic and cardiovascular effects, which can lead to vision loss and cardiotoxicity. This article describes relevant negative impacts of these drugs on the cardiovascular system. The performance of several clinical trials with CQ and HCQ in COVID-19 patients leads to an ineffectiveness of these drugs. The absence of efficacy, in addition to potential deleterious effects on the cardiovascular system, suggest that this pharmacological approach should be used with caution, especially due to the large number of patients with COVID-19 who have pre-existing cardiovascular disorders.

\section{Potential Conflict of Interest}

No potential conflict of interest relevant to this article was reported.

\section{Sources of Funding}

There were no external funding sources for this study.

\section{Study Association}

This study is not associated with any thesis or dissertation work.

\section{Author Contributions}

Conception and design of the research: Brazão SC, Autran LJ, Lopes RO, Scaramello CBV, Brito FCF, Motta NAV. Writing of the manuscript: Brazão SC, Autran LJ, Lopes RO, Scaramello CBV, Brito FCF, Motta NAV. Critical revision of the manuscript for intellectual content: Brito FCF, Motta NAV.

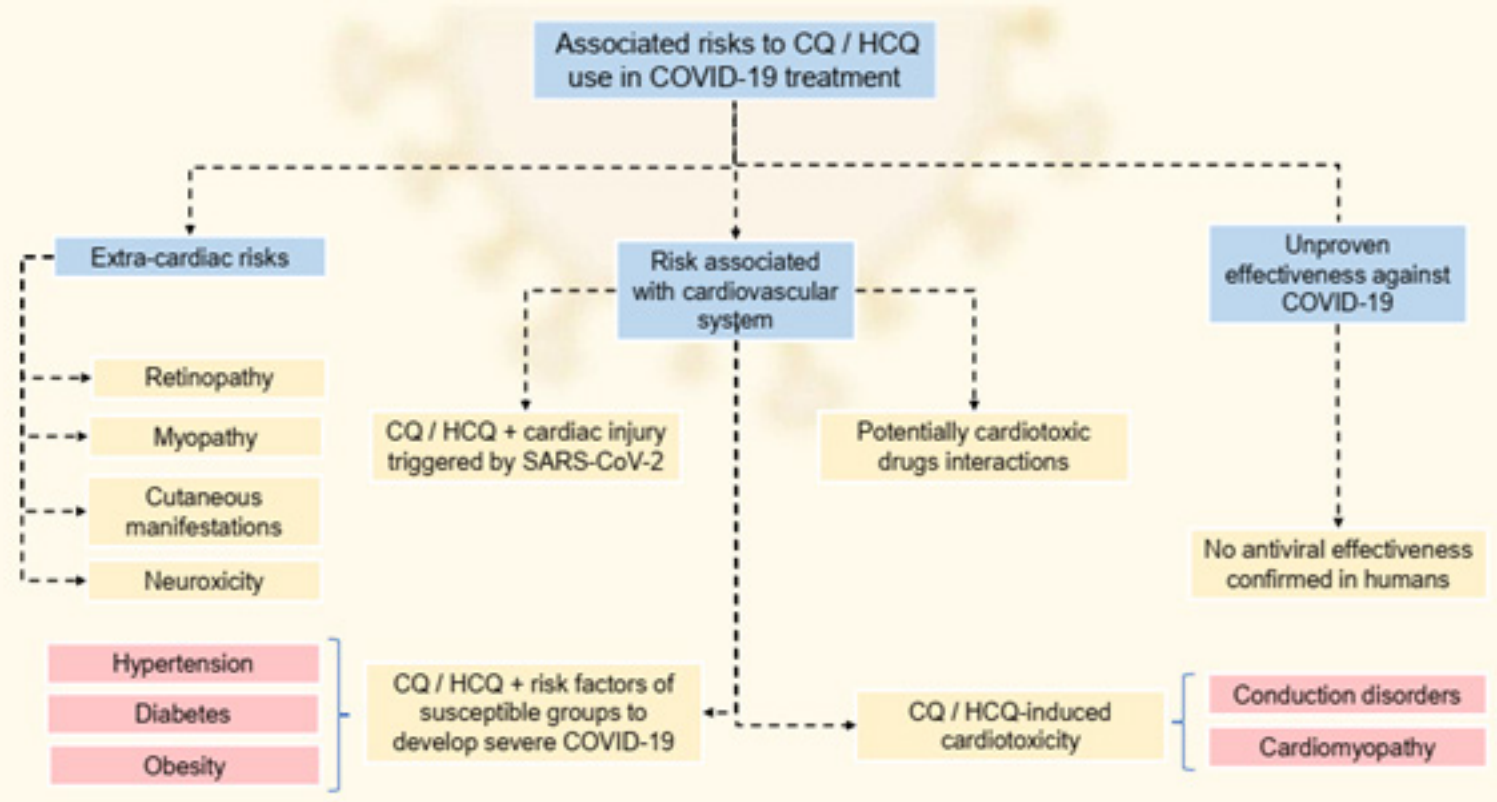

Figure 1 - Associated risks with CQ and HCQ use in the treatment of patients with COVID-19. 


\section{References}

1. World Health Organization. Coronavirus disease (COVID-19) pandemic. [acesso em 01 de junho de 2020]. Disponível em: https://www.who.int/emergencies/diseases/novel-coronavirus-2019.

2. Touret F, Lamballerie X. Of chloroquine and COVID-19. Antiviral Res. 2020 May; $177: 104762$.

3. Slater AFG. Chloroquine: mechanism of drug action and resistance in plasmodium falciparum. Pharmacol Ther. 1993;57(2-3):203-35.

4. Costedoat-Chalumeau N, Leroux G, Amoura Z, Piette JC. Hydroxychloroquine dans le traitement du lupus : le renouveau. Rev Med Interne. 2008;29(9):735-7.

5. Ruiz-Irastorza G, Ramos-Casals M, Brito-Zeron P, Khamashta MA Clinical efficacy and side effects of antimalarials in systemic lupus erythematosus: A systematic review. Ann Rheum Dis. 2010;69(1):20-8.

6. Schrezenmeier E, Dörner T. Mechanisms of action of hydroxychloroquine and chloroquine: implications for rheumatology. Nat Rev Rheumatol. 2020;16(3):155-66

7. Gérard JM, Stoupel N, Collier A, Flament-Durand J. Morphologic study of a neuromyopathy caused by prolonged chloroquine treatment. Eur Neurol. 1973;9(6):363-79.

8. Alarcón GS, McGwin G, Bertoli AM, Fessler BJ, Calvo-Alén J, Bastian $\mathrm{HM}$, et al. Effect of hydroxychloroquine on the survival of patients with systemic lupus erythematosus: Data from LUMINA, a multiethnic US cohort (LUMINA L). Ann Rheum Dis. 2007;66(9):1168-72.

9. Petri M. Use of hydroxychloroquine to prevent thrombosis in systemic lupus erythematosus and in antiphospholipid antibody-positive patients. Curr Rheumatol Rep. 2011;13(1):77-80

10. Pons-Estel GJ, Alarcón GS, Hachuel L, Boggio G, Wojdyla D, PascualRamos V, et al. Anti-malarials exert a protective effect while mestizo patients are at increased risk of developing SLE renal disease: Data from a Latin-American cohort. Rheumatol (Oxford). 2012;51(7):1293-8.

11. Jorge A, Ung C, Young LH, Melles RB, Choi HK. Hydroxychloroquine retinopathy- implications of research advances for rheumatology care. Nat Rev Rheumatol. 2018;14(12):693-703.

12. Raines MF, Bhargava SK, Rosen ES. The blood-retinal barrier in chloroquine retinopathy. Investig Ophthalmol Vis Sci. 1989; 30(8):1726-31.

13. Cotter C, Sturrock HJW, Hsiang MS, Liu J, Phillips AA, Hwang J, et al. The changing epidemiology of malaria elimination: New strategies for new challenges. Lancet. 2013;382(9895):900-11.

14. Wasko MCM, Hubert HB, Lingala VB, Elliott JR, Luggen ME, Fries JF, et al. Risk of diabetes in patients with rheumatoid arthritis taking hydroxychloroquine. JAMA. 2007;298(20):2368-9.

15. Schneider JG, Finck BN, Ren J, Standley KN, Takagi M, Maclean KH, et al. ATM-dependent suppression of stress signaling reduces vascular disease in metabolic syndrome. Cell Metab. 2006;4(5):377-89.

16. Nelson AA, Fitahugh OG. Chloroquine (SN-7618) pathologic changes observed in rats which for 2 years had been fed various proportions. Arch Pathol. 1948;45(4):454-62.

17. Alving AS, Eichelberger L. Studies on the chronic toxicity of chloroquine (SN-7618). J Clin Invest. 1948;27(3 Pt1):60-5.

18. Tönnesmann E, Kandolf R, Lewalter T. Chloroquine cardiomyopathy-a review of the literature. Immunopharmacol Immunotoxicol. 2013;35(3):434-42.

19. Cambiaggi A. Unusual ocular lesions in a case of systemic lupus erythematosus. AMA Arch Ophthalmol. 1957;57(3):451-3.

20. Loftus LR. Peripheral neuropathy following chloroquine therapy. Can Med Assoc J. 1963;89(18):917-20.

21. Whisnant JP, Espinosa RE, Kierland RR, Lambert EH. Chloroquine neuromyopathy. Proc Staff Meet Mayo Clin. 1963 Nov 6;38:501-13.
22. Hughes JT, Esiri M, Oxbury JM, Whitty CW. Chloroquine myopathy. Q J Med. 1971;40(157):85-93.

23. Edwards AC, Meredith TJ, Sowton E. Complete heart block due to chronic chloroquine toxicity managed with permanent pacemaker. Br Med J. 1978;1(6120):1109-10.

24. Ben-Zvi I, Kivity S, Langevitz P, Shoenfeld Y. Hydroxychloroquine: from malaria to autoimmunity. Clin Rev Allergy Immunol. 2012;42(2):145-53.

25. Ding HJ, Denniston AK, Rao VK, Gordon C. Hydroxychloroquine-related retinal toxicity. Rheumatology (Oxford). 2016;55(6):957-67.

26. Smith ER, Klein-Schwartz W. Are 1-2 dangerous? Chloroquine and hydroxychloroquine exposure in toddlers. J Emerg Med. 2005;28(4):437-43.

27. Friedman D, Lovig L, Halushka M, Clancy RM, Izmirly PM, Buyon JP. No histologic evidence of foetal cardiotoxicity following exposure to maternal hydroxychloroquine. Clin Exp Rheumatol. 2017;35(5):857-85.

28. Tett S, Cutler D, Day R, Brown K. Bioavailability of hydroxychloroquine tablets in healthy volunteers. Br J Clin Pharmacol. 1989;27(6):771-9.

29. Rubin M, Zvaifler N, Bernstein H MA,Mansour A. Chloroquine toxicity. In: Brodie BB, Gillette JR. Drug and enzymes: Proceedings of the Second International Pharmacological Meeting. Oxford: Pergamon Press;1965. v.4. p:467-87

30. Frisk-Holmberg M, Bergqvist Y, Englund U. Chloroquine intoxication. Br J Clin Pharmacol. 1983;15(4):502-3.

31. Inglot AD. Comparison of the antiviral activity in vitro of some nonsteroidal antiinflammatory drugs. J Gen Virol. 1969;4(2):203-14.

32. Miller DK, Lenard J. Antihistaminics, local anesthetics, and other amines as antiviral agents. Proc Natl Acad Sci U S A. 1981;78(6):3605-9.

33. Shimizu Y, Yamamoto S, Homma NI. M, Ishida N. Effect of chloroquine on the growth of animal viruses. Arch Gesamte Virusforsch. 1972;36(1):93-104.

34. Keyaerts E, Vijgen L, Maes P, Neyts J, Ranst M. In vitro inhibition of severe acute respiratory syndrome coronavirus by chloroquine. Biochem Biophys Res Commun. 2004;323(1):264-8.

35. Tan CYQ, Gonfrier G, Ninove L, Zandotti C, Dubot-Pérès A, Lamballerie $X$, et al. Screening and detection of human enterovirus 71 infection by a real-time RT-PCR assay in Marseille, France, 2009-2011. Clin Microbiol Infect. 2012;18(4):E77-80.

36. Li W, Hulswit RJG, Widjaja I, Raj VS, McBride R, Peng W, et al. Identification of sialic acid-binding function for the Middle East respiratory syndrome coronavirus spike glycoprotein. Proc Natl Acad Sci U S A. 2017;114(40):E8508-17.

37. Yan $Y$, Zou Z, Sun $Y$, Li X, Xu KF, Wei Y, et al. Anti-malaria drug chloroquine is highly effective in treating avian influenza A H5N1 virus infection in an animal model. Cell Res. 2013;23(2):300-2.

38. Paton NI, Goodall RL, Dunn DT, Franzen S, Collaco-Moraes Y, Gazzard BG, et al. Effects of hydroxychloroquine on immune activation and disease progression among HIV-infected patients not receiving antiretroviral therapy: a randomized controlled trial. JAMA. 2012;308(4):353-61.

39. Tricou V, Minh NN, Van TP, Lee SJ, Farrar J, Wills B, et al. A randomized controlled trial of chloroquine for the treatment of dengue in vietnamese adults. PLoS Negl Trop Dis. 2010;4(8):e785.

40. Dowall SD, Bosworth A, Watson R, Bewley K, Taylor I, Rayner E, et al. Chloroquine inhibited Ebola virus replication in vitro but failed to protect against infection and disease in the in vivo guinea pig model. J Gen Virol. 2015;96(12):3484-92.

41. Falzarano D, Safronetz D, Prescott J, Marzi A, Feldmann F, Feldmann $\mathrm{H}$. Lack of protection against Ebola virus from chloroquine in mice and hamsters. Emerg Infect Dis. 2015;21(6):1065-7. 
42. Pallister J, Middleton D, Crameri G, Yamada M, Klein R, Hancock TJ, et al. Chloroquine administration does not prevent Nipah virus infection and disease in ferrets. J Virol. 2009;83(22):11979-82.

43. Vigerust DJ, McCullers JA. Chloroquine is effective against influenza A virus in vitro but not in vivo. Influenza Other Respi Viruses. 2007;1(5-6):189-92.

44. Coombs K, Mann E, Edwards J, Brown DT. Effects of chloroquine and cytochalasin B on the infection of cells by Sindbis virus and vesicular stomatitis virus. J Virol. 1981;37(3):1060-5.

45. De Lamballerie X, Boisson V, Reynier JC, Enault S, Charrel RN, Flahault A, et al. On chikungunya acute infection and chloroquine treatment. Vector-Borne Zoonotic Dis. 2008;8(6):837-9.

46. Maheshwari RK, Srikantan V, Bhartiya D. Chloroquine enhances replication of Semliki Forest virus and encephalomyocarditis virus in mice. J Virol. 1991;65(2):992-5.

47. Roques P, Thiberville SD, Dupuis-Maguiraga L, Lum FM, Labadie $\mathrm{K}$, Martinon F, et al. Paradoxical effect of chloroquine treatment in enhancing chikungunya virus infection. Viruses. 2018;10(5):268

48. Connolly KM, Stecher VJ, Danis E, Pruden DJ, LaBrie T. Alteration of interleukin-1 production and the acute phase response following medication of adjuvant arthritic rats with cyclosporin-A or methotrexate. Int J Immunopharmacol. 1988;10(6):717-28.

49. Katz SJ, Russell AS. Re-evaluation of antimalarials in treating rheumatic diseases: Re-appreciation and insights into new mechanisms of action. Curr Opin Rheumatol. 2011;23(3):278-81.

50. Savarino A, Lucia MB, Rastrelli E, Rutella S, Golotta C, Morra E, et al Anti-HIV effects of chloroquine: inhibition of viral particle glycosylation and synergism with protease inhibitors. J Acquir Immune Defic Syndr. $2004 ; 35(3): 223-32$.

51. Engchanil C, Kosalaraksa P, Lumbiganon P, Lulitanond V, Pongjunyakul $\mathrm{P}$, Thuennadee $\mathrm{R}$, et al. Therapeutic potential of chloroquine added to zidovudine plus didanosine for HIV-1 infected children. J Med Assoc Thai. 2006;89(8):1229-36.

52. Mehra MR, Desai SS, Ruschitzka F, Patel AN. Hydroxychloroquine or chloroquine with or without a macrolide for treatment of COVID-19: a multinational registry analysis. Lancet. 2020;6736(20):31180-6.

53. Sharma TS, Wasko MCM, Tang X, Vedamurthy D, Yan X, Cote J, et al. Hydroxychloroquine use is associated with decreased incident cardiovascular events in rheumatoid arthritis patients. J Am Heart Assoc. 2016;5(1):e002867.

54. Sun L, Liu M, Li R, Zhao Q, Liu J, Yang Y, et al. Hydroxychloroquine, a promising choice for coronary artery disease? Med Hypotheses. 2016 Aug;93:5-7

55. Page RL, O'bryant CL, Cheng D, Dow TJ, Ky B, Stein CM, et al. Drugs that may cause or exacerbate heart failure: a scientific statement from the American Heart Association. Circulation. 2016;134(6):e32-69.

56. Chatre C, Roubille F, Vernhet H, Jorgensen C, Pers YM. Cardiac complications attributed to chloroquine and hydroxychloroquine: a systematic review of the literature. Drug Saf. 2018;41(10):919-31.

57. Lenfant T, Dion J, Maisonobe T, Costedoat-Chalumeau N. A rare cause of impaired general condition: muscular and cardiac toxicity of antimalarials. Rev Med Interne. 2020;41(5):335-8.

58. Lee JH, Chung WB, Kang JH, Kim HW, Kim JJ, Kim JH, et al. A case of chloroquine-induced cardiomyopathy that presented as sick sinus syndrome. Korean Circ J. 2010;40(11):604-8

59. Chatre C, Filippi N, Roubille F, Pers YM. Heart involvement in a woman treated with hydroxychloroquine for systemic lupus erythematosus revealing fabry disease. J Rheumatol. 2016;43(5):997-8.

60. Baguet JP, Tremel F, Fabre M. Chloroquine cardiomyopathy with conduction disorders. Heart. 1999;81(2):221-3.

61. Naqvi TZ, Luthringer D, Marchevsky A, Saouf R, Gul K, Buchbinder NA. Chloroquine-induced cardiomyopathy-echocardiographic features. J Am Soc Echocardiogr. 2005;18(4):383-7.
62. Cotroneo J, Sleik KM, Rodriguez ER, Klein AL. Hydroxychloroquineinduced restrictive cardiomyopathy: correlation between clinical, echocardiographic and pathologic findings. Eur J Echocardiogr. 2007;8(4):247-51.

63. Reffelmann T, Naami A, Spuentrup E, Kühl HP. Contrast-enhanced magnetic resonance imaging of a patient with chloroquine-induced cardiomyopathy confirmed by endomyocardial biopsy. Circulation. 2006;114(8):357-9.

64. Cubero II, Lopez-Espinosa MTP, Richardson AC. Enantiospecific synthesis fromD-fructose of (2S,5R)- and (2R,5R)-2-methyl-1,6dioxaspiro[4.5]decane [the odor bouquet minor components of Paravespula Vulgaris (L.)]. J Chem Ecol. 1993;19(6):1265-83.

65. Cervara A, Espinosa G, Font J, Ingelmo M. Cardiac toxicity secondary to long term treatment with chloroquine. Ann Rheum Dis. 2001;60(3):301.

66. Nord JE, Shah PK, Rinaldi RZ, Weisman MH. Hydroxychloroquine cardiotoxicity in systemic lupus erythematosus: a report of 2 cases and review of the literature. Semin Arthritis Rheum. 2004;33(5):336-51.

67. Costedoat-Chalumeau N, Hulot JS, Amoura Z, Delcourt A, Maisonobe $\mathrm{T}$, Dorent $\mathrm{R}$, et al. Cardiomyopathy related to antimalarial therapy with illustrative case report. Cardiology. 2007;107(2):73-80.

68. Yogasundaram H, Hung W, Paterson ID, Sergi C, Oudit GY. Chloroquineinduced cardiomyopathy: a reversible cause of heart failure. ESC Hear Fail. 2018;5(3):372-5

69. Dogar MU, Shah NN, Ishtiaq S, Shah PN, Shah P, Mathew S, et al Hydroxychloroquine-induced restrictive cardiomyopathy: a case report. Postgrad Med J. 2018;94(1109):185-6.

70. Joyce E, Fabre A, Mahon N. Hydroxychloroquine cardiotoxicity presenting as a rapidly evolving biventricular cardiomyopathy: key diagnostic features and literature review. Eur Heart J Acute Cardiovasc Care. 2013;2(1):77-83

71. Jankelson L, Karam G, Becker ML, Chinitz LA, Tsai M-C. QT prolongation, torsades de pointes and sudden death with short courses of chloroquine or hydroxychloroquine as used in COVID-19: a systematic review. Heart Rhythm. 2020;17(9):1472-9.

72. Capel RA, Herring N, Kalla M, Yavari A, Mirams GR, Douglas G, et al. Hydroxychloroquine reduces heart rate by modulating the hyperpolarization-activated current If: Novel electrophysiological insights and therapeutic potential. Heart Rhythm. 2015;12(10):2186-94.

73. Traebert M, Dumotier B, Meister L, Hoffmann P, Dominguez-Estevez M Suter W. Inhibition of hERG K+ currents by antimalarial drugs in stably transfected HEK293 cells. Eur J Pharmacol. 2004;484(1):41-8.

74. Sanghvi LM, Mathurm BBS. Electrocardiogram after chloroquine and emetine. Circulation. 1965;32(2):281-9.

75. McGhie TK, Harvey P, Su J, Anderson N, Tomlinson G, Touma Z Electrocardiogram abnormalities related to anti-malarials in systemic lupus erythematosus. Clin Exp Rheumatol. 2018;36(4):545-51.

76. Queyriaux B, Carlioz R, Perrier E, Micaelli P, Gressard A, Deroche J, et al. Les effets cardiovasculaires liés à l'utilisation de la chloroquine. Ann Cardiol Angeiol (Paris). 2001;50(5):285-92.

77. Rey LD, Berneck A, Gonçalves L, Silva MB, Skare TL, Silva JA. ECG QT Interval prolongation in rheumatic patients using antimalarial drugs. Rev Bras Reumatol. 2003;43(5):275-8.

78. Newton-Cheh $\mathrm{C}$, Lin AE, Baggish AL, Wang H. Case records of the Massachusetts General Hospital. Case 11-2011: a 47-year-old man with systemic lupus erythematosus and heart failure. N Engl J Med. 2011;364(15):1450-60

79. Chen CY, Wang FL, Lin CC. Chronic hydroxychloroquine use associated with QT prolongation and refractory ventricular arrhythmia. Clin Toxicol. 2006;44(2):173-5

80. Stas P, Faes D, Noyens P. Conduction disorder and QT prolongation secondary to long-term treatment with chloroquine. Int J Cardiol. 2008;127(2):e80-2. 
81. Shah SR, Park K, Alweis R. Long QT syndrome: a comprehensive review of the literature and current evidence. Curr Probl Cardiol. 2019;44(3):92-106

82. O'Laughlin JP, Mehta PH, Wong BC. Life threatening severe QTc prolongation in patient with systemic lupus erythematosus due to hydroxychloroquine. Case Rep Cardiol. 2016 Jul 12;2016:4626279.

83. Broek MPH, Möhlmann JE, Abeln BGS, Liebregts M, Dijk VF, Garde EMW. Chloroquine-induced QTc prolongation in COVID-19 patients. Neth Heart J. 2020;28(7):406-9

84. Saleh M, Gabriels J, Chang D, Kim BS, Mansoor A, Mahmood E, et al. The Effect of chloroquine, hydroxychloroquine and azithromycin on the corrected QT interval in patients with SARS-CoV-2 infection. Circ Arrhythm Electrophysiol. 2020;13(6).e008662.

85. Szekely Y, Lichter Y, Shrkihe BA, Bruck H, Oster HS, Viskin S. Chloroquine-induced torsade de pointes in a patient with coronavirus disease 2019. Heart Rhythm. 2020;17(9):1452-5

86. Chorin E, Wadhwani L, Magnani S, Dai M, Shulman E, Nadeau-Routhier C, et al. QT interval prolongation and torsade de pointes in patients with COVID-19 treated with hydroxychloroquine/azithromycin. Heart Rhythm. 2020;17(9):1425-33.

87. Rosenberg ES, Dufort EM, Udo T, Wilberschied LA, Kumar J, Tesoriero J, et al. Association of treatment with hydroxychloroquine or azithromycin with in-hospital mortality in patients with COVID-19 in New York state. JAMA. 2020;323(24):2493-502.

88. Guedira N, Hajjaj-Hassouni N, Srairi JE, El Hassani S, Fellat R, Benomar $\mathrm{M}$. Third-degree atrioventricular block in a patient under chloroquine therapy. Rev Rhum Engl Ed. 1998;65(1):58-62.

89. Godeau P, Guillevin L, Fechner J, Bletry O, Herreman G. Les troubles de conduction au cours du lupus érythémateux. Fréquence et incidence dans une population de 112 patients. Ann Med Interne (Paris). 1981;132(4):234-40.

90. Fourcade L, Camus O, Roche N, Chenilleau MC, Gil JM, Massoure PL. Bloc de branche gauche douloureux d'effort associé à la chimioprophylaxie antipaludique par chloroquine. Med Sante Trop. 2014;24(3):320-2.

91. Ogola ES, Muita AK, Adala H. Chloroquine related complete heart block with blindness: case report. East Afr Med J. 1992;69(1):50-2.

92. Dodson MW, Brown LM, Elliott CG. Pulmonary arterial hypertension. Heart Fail Clin. 2018;14(3):255-69.

93. Wu K, Zhang Q, Wu X, Lu W, Tang H, Liang Z, et al. Chloroquine is a potent pulmonary vasodilator that attenuates hypoxia-induced pulmonary hypertension. Br J Pharmacol. 2017;174(22):4155-72.

94. Long L, Yang X, Southwood M, Lu J, Marciniak SJ, Dunmore BJ, et al. Chloroquine prevents progression of experimental pulmonary hypertension via inhibition of autophagy and lysosomal bone morphogenetic protein type II receptor degradation. Circ Res. 2013;112(8):1159-70.

95. Dunmore BJ, Drake KM, Upton PD, Toshner MR, Aldred MA, Morrell NW. The lysosomal inhibitor, chloroquine, increases cell surface BMPRII levels and restores BMP9 signalling in endothelial cells harbouring BMPR-II mutations. Hum Mol Genet. 2013;22(18):3667-79.

96. Opitz CF, Hoeper MM, Gibbs JSR, Kaemmerer H, Pepke-Zaba J, Coghlan JG, et al. Pre-capillary, combined, and post-capillary pulmonary hypertension: a pathophysiological continuum. J Am Coll Cardiol. 2016;68(4):368-78.

97. Rainsford KD, Parke AL, Clifford-Rashotte M, Kean WF. Therapy and pharmacological properties of hydroxychloroquine and chloroquine in treatment of systemic lupus erythematosus, rheumatoid arthritis and related diseases. Inflammopharmacology. 2015;23(5):231-69.

98. Schrezenmeier E, Dörner T. Mechanisms of action of hydroxychloroquine and chloroquine: implications for rheumatology. Nat Rev Rheumatol. 2020;16(3):155-66.

99. Adjepon-Yamoah K, Woolhouse N, Prescott LF. The effect of chloroquine on paracetamol disposition and kinetics. Br J Clin Pharmacol 1986;21(3):322-4.
100. Raina RK, Bano G, Amla V, Kapoor V, Gupta KL. The effect of aspirin, paracetamol and analgin on pharmacokinetics of chloroquine. Indian J Physiol Pharmacol. 1993;37(3):229-31.

101. Gupta JD, Gruca M, Ablett W. Effect of other drugs and chemicals on the degradation of aspirin in vitro: possible extrapolation to in vivo metabolism of aspirin. Eur J Drug Metab Pharmacokinet. 1978;4(2):103-8.

102. Leden I. Digoxin-hydroxychloroquine interaction? Acta Med Scand. 1982;211(5):411-2.

103. Somer M, Kallio J, Pesonen U, Pyykkö K, Huupponen R, Scheinin $\mathrm{M}$. Influence of hydroxychloroquine on the bioavailability of oral metoprolol. Br J Clin Pharmacol. 2000;49(6):549-54.

104. Gautret P, Lagier JC, Parola P, Hoang VT, Meddeb L, Mailhe M, et al. Hydroxychloroquine and azithromycin as a treatment of COVID-19: results of an open-label non-randomized clinical trial. Int J Antimicrob Agents. 2020;56(1):105949.

105. Million M, Lagier JC, Gautret P, Colson P, Fournier PE, Amrane S, et al. Early treatment of COVID-19 patients with hydroxychloroquine and azithromycin: a retrospective analysis of 1061 cases in Marseille, France. Travel Med Infect Dis. 2020 May-June;35:101738.

106. Fantini J, Chahinian H, Yahi N. Synergistic antiviral effect of hydroxychloroquine and azithromycin in combination against SARSCoV-2: what molecular dynamics studies of virus-host interactions reveal. Int J Antimicrob Agents. 2020;56(2):106020.

107. Vicente J, Zusterzeel R, Johannesen L, Ochoa-Jimenez R, Mason JW, Sanabria C, et al. Assessment of multi-ion channel block in a phase I randomized study design: results of the CiPA phase I ECG biomarker validation study. Clin Pharmacol Ther. 2019;105(4):943-53.

108. Molina JM, Delaugerre C, Le Goff J, Mela-Lima B, Ponscarme D, Goldwirt $\mathrm{L}$, et al. No evidence of rapid antiviral clearance or clinical benefit with the combination of hydroxychloroquine and azithromycin in patients with severe COVID-19 infection. Med Mal Infect. 2020;50(4):384.

109. Furst DE. Pharmacokinetics of hydroxychloroquine and chloroquine during treatment of rheumatic diseases. Lupus. 1996;5(Suppl 1):S11-5.

110. Bannwarth B, Péhourcq F, Schaeverbeke T, Dehais J. Clinical pharmacokinetics of low-dose pulse methotrexate in rheumatoid arthritis. Clin Pharmacokinet. 1996;30(3):194-210.

111. Nampoory MR, Nessim J, Gupta RK, Johny KV. Drug interaction of chloroquine with ciclosporin. Nephron. 1992;62(1):108-9.

112. Borne BE, Landewé RB, Goei The HS, Rietveld JH, Zwinderman AH, Bruyn GA, et al. Combination therapy in recent onset rheumatoid arthritis: a randomized double blind trial of the addition of low dose cyclosporine to patients treated with low dose chloroquine. J Rheumatol. 1998;25(8):1493-8.

113. Ali HM. Reduced ampicillin bioavailability following oral coadministration with chloroquine. J Antimicrob Chemother. 1985;15(6):781-4.

114. Ilo CE, Ezejiofor NA, Agbakoba N, Brown SA, Maduagwuna CA, Agbasi $\mathrm{PU}$, et al. Effect of chloroquine on the urinary excretion of ciprofloxacin. Am J Ther. 2008;15(5):419-22.

115. Namazi MR. The potential negative impact of proton pump inhibitors on the immunopharmacologic effects of chloroquine and hydroxychloroquine. Lupus. 2009;18(2):105-5

116. Marmor MF, Kellner U, Lai TYY, Melles RB, Mieler WF, American Academy of Ophthalmology. Recommendations on screening for chloroquine and hydroxychloroquine retinopathy (2016 revision). Ophthalmology. 2016;123(6):1386-94.

117. Melles RB, Marmor MF. The risk of toxic retinopathy in patients on long-term hydroxychloroquine therapy. JAMA Ophthalmol. 2014;132(12):1453-60.

118. Yusuf IH, Sharma S, Luqmani R, Downes SM. Hydroxychloroquine retinopathy. Eye (Lond). 2017;31(6):828-45. 
119. Ponticelli C, Moroni G. Hydroxychloroquine in systemic lupus erythematosus (SLE). Expert Opin Drug Saf. 2017;16(3):411-9.

120. Tsang AC, Ahmadi Pirshahid S, Virgili G, Gottlieb CC, Hamilton J, Coupland SG. Hydroxychloroquine and chloroquine retinopathy: a systematic review evaluating the multifocal electroretinogram as a screening test. Ophthalmology. 2015;122(6):1239-51.e4.

121. Soria A, Barbaud A, Assier H, Avenel-Audran M, Tétart F, Raison-Peyron $\mathrm{N}$, et al. Cutaneous adverse drug reactions with antimalarials and allergological skin tests. Dermatology. 2015;231(4):353-9.

122. Le Quintrec JS, Le Quintrec JL. Drug-induced myopathies. Baillieres Clin Rheumatol. 1991;5(1):21-38.

123. Huang C, Wang Y, Li X, Ren L, Zhao J, Hu Y, et al. Clinical features of patients infected with 2019 novel coronavirus in Wuhan, China. Lancet. 2020;395(10223):497-506

124. Zheng Z, Peng F, Xu B, Zhao J, Liu H, Peng J, et al. Risk factors of critical \& mortal COVID-19 cases: a systematic literature review and meta-analysis. J Infect. 2020;81(2):e16-25.

125. Sanchis-Gomar F, Lavie CJ, Mehra MR, Henry BM, Lippi G. Obesity and outcomes in COVID-19: when an epidemic and pandemic collide. Mayo Clin Proc. 2020;95(7):1445-53.

126. Boopathi S, Poma AB, Kolandaivel P. Novel 2019 Coronavirus structure, mechanism of action, antiviral drug promises and rule out against its treatment. J Biomol Struct Dyn. 2020 Apr 30. [Epub ahead of print].

127. Gheblawi M, Wang K, Viveiros A, Nguyen Q, Zhong JC, Turner AJ, et al. Angiotensin-converting enzyme 2: SARS-CoV-2 receptor and regulator of the renin-angiotensin system: celebrating the 20th anniversary of the discovery of ACE2. Circ Res. 2020;126(10):1456-74.

128. South AM, Diz DI, Chappell MC. COVID-19, ACE2, and the cardiovascular consequences. Am J Physiol Heart Circ Physiol. 2020;318(5):H1084-90.

129. Lei J, Li J, Li X, Qi X. CT imaging of the 2019 novel coronavirus (2019nCoV) pneumonia. Radiology. 2020;295(1):18.

130. Li B, Yang J, Zhao F, Zhi L, Wang X, Liu L, et al. Prevalence and impact of cardiovascular metabolic diseases on COVID-19 in China. Clin Res Cardiol. 2020;109(5):531-8.
131. Ruan Q, Yang K, Wang W, Jiang L, Song J. Clinical predictors of mortality due to COVID-19 based on an analysis of data of 150 patients from Wuhan, China. Intensive Care Med. 2020;46(5):846-8.

132. Mehta P, McAuley DF, Brown M, Sanchez E, Tattersall RS, Manson JJ, et al COVID-19: consider cytokine storm syndromes and immunosuppression. Lancet. 2020;395(10229):1033-4.

133. Wong CK, Lam CWK, Wu AKL, Ip WK, Lee NLS, Chan IHS, et al. Plasma inflammatory cytokines and chemokines in severe acute respiratory syndrome. Clin Exp Immunol. 2004;136(1):95-103.

134. Zheng YY, Ma YT, Zhang JY, Xie X. COVID-19 and the cardiovascular system. Nat Rev Cardiol. 2020;17(5):259-60.

135. Clerkin KJ, Fried JA, Raikhelkar J, Sayer G, Griffin JM, Masoumi A, et al. (COVID-19) and cardiovascular disease. Circulation. 2020;141(20):1648-55.

136. Vincent MJ, Bergeron E, Benjannet S, Erickson BR, Rollin PE, Ksiazek TG, et al. Chloroquine is a potent inhibitor of SARS coronavirus infection and spread.Virol J.2005;2:1-10.

137. Borges MC, Castro LA, Fonseca BAL. Chloroquine use improves denguerelated symptoms. Mem Inst Oswaldo Cruz. 2013;108(5):596-9.

138.Toumi M, Aballea S. Commentary on "Hydroxychloroquine and azithromycin as a treatment of COVID-19: results of an open label nonrandomized clinical trial" by Gautret et al. J Mark Access Health Policy. 2020;8(1):1758390.

139. Tang W, Cao Z, Han M, Wang Z, Chen J, Sun W, et al. Hydroxychloroquine in patients with mainly mild to moderate coronavirus disease 2019: open label, randomised controlled trial. BMJ. 2020;369:m1849.

140. Geleris J, Sun Y, Platt J, Zucker J, Baldwin M, Hripcsak G, et al Observational study of hydroxychloroquine in hospitalized patients with COVID-19. N Engl J Med. 2020;382(25):2411-8.

141. Mahévas M, Tran VT, Roumier M, Chabrol A, Paule R, Guillaud C, et al. Clinical efficacy of hydroxychloroquine in patients with covid-19 pneumonia who require oxygen: observational comparative study using routine care data. BMJ. 2020;369:m2328.

142. Borba MGS, Val FFA, Sampaio VS, Alexandre MAA, Melo GC, Brito M, et al. Effect of high vs low doses of chloroquine diphosphate as adjunctive therapy for patients hospitalized with severe acute respiratory syndrome coronavirus 2 (SARS-CoV-2) infection: a randomized clinical trial. JAMA Netw Open. 2020;3(4):e208857. 